\title{
Two Anatomically Specific Classes of Candidate Cholinoceptive Neurons in the Rat Olfactory Bulb
}

\author{
W. T. Nickell and M. T. Shipley \\ Department of Anatomy and Cell Biology, University of Cincinnati College of Medicine, Cincinnati, Ohio 45267
}

The pharmacohistochemical technique of Butcher (1978) and choline acetyltransferase (ChAT) immunocytochemistry were used to demonstrate the presence, morphology, and differential distribution of 2 classes of acetylcholinesterase (AChE)-positive, ChAT-negative neurons in the rat olfactory bulb. One population of these neurons is located preferentially in a stratum just deep to the mitral cell layer (mcl). These AChE-positive inframitral neurons are significantly larger than the predominant inframitral neuronal type, the granule cell. Inframitral AChE-positive neurons appear to send processes deeper into the granule cell layer and superficially into the external plexiform layer (epl), above the mcl. Neurophysiological experiments reported in a companion article are consistent with the existence of a population of cholinoceptive neurons with the location and characteristics of these large inframitral interneurons.

A second class of AChE-positive, ChAT-negative neurons is found exclusively in the glomerular layer. These neurons are located primarily in the periglomerular region and the superficial third of the epl; they are somewhat larger than typical periglomerular cells. Juxtaglomerular AChE neurons are smaller than inframitral AChE neurons.

Since there are no neurons in the olfactory bulb that produce ChAT, the synthetic enzyme for ACh, the AChE-positive cells reported here are hypothesized to be cholinoceptive neurons for the cholinergic projection from the basal forebrain to the olfactory bulb. Anatomical, physiological, and receptor-ligand binding data are consistent with this interpretation.

All forebrain cortical structures receive projections from a related group of nuclei in the basal forebrain (Mesulam et al., $1983 a, b)$. A significant proportion of the neurons in these projections are cholinergic. Pharmacological blockade of muscarinic transmission results in serious disruption of behavioral function, including loss of spatial memory (Eckerman et al., 1980; Watts et al., 1981); degeneration of the cholinergic component of the projections from basal forebrain to neocortex and hippocampus has been associated with profound cognitive dys-

\footnotetext{
Received July 7, 1987; revised Mar. 2, 1988; accepted May 3, 1988.

We wish to thank Beata Frydel, Karen Wilburn, and Ying Tsai for their excellent histological work, Ying Tsai for printing the photomicrographs, Mr. Jesus Luna for programming of the image-analysis computer, and Ms. Sharon Harding for secretarial assistance.

This work was supported in part by the U.S. Army Medical Research and Development Command, Contract Number DAMD 17-86-C-6005 and by NIH NS 20643-01 and NS 23348.

Correspondence should be addressed to Dr. M. T. Shipley at the above address. Copyright $(1988$ Society for Neuroscience $0270-6474 / 88 / 124482-10 \$ 02.00 / 0$
}

function and memory loss in human Alzheimer's patients (Whitehouse et al., 1981, 1982; Coyle et al., 1983). These and numerous other observations suggest that cholinergic basal forebrain neurons play an integral role in cortical function. A better understanding of basal forebrain circuitry, therefore, should provide new insights into the principles of cortical function and mechanisms of cortical degenerative diseases.

A significant limitation to our understanding of these systems is that we do not know the synaptic elements upon which basal forebrain afferents terminate in their cortical targets. Chandler and Crutcher (1983) reported that HRP transported from the medial septum is localized in synapses on the cell bodies of granule cells and the somata and dendrites of interneurons, probably basket cells. However, since both cholinergic and GABAergic neurons contribute to the septohippocampal projection (Rye et al., 1984; Amaral and Kurz, 1985; Wainer et al., 1985; Zaborszky et al., 1986), it is not possible to distinguish the targets of cholinergic and GABAergic synapses from such transport studies. Electron microscopic studies of the localization of choline acetyltransferase (ChAT) (Wainer et al., 1984b; Frotscher and Leranth, 1985) demonstrate that cholinergic terminals in the hippocampus and neocortex make synaptic contact with a variety of postsynaptic neuronal types; however, it is not clear from these descriptive studies whether ChAT-positive synapses derive from extrinsic medial septal or from intrinsic cholinergic interneurons.

Physiological studies have provided information about the actions and possible cellular targets of cholinergic synapses in the hippocampus. Application of cholinergic agonists among the dendrites of pyramidal cells inhibits release of transmitter from the terminals of afferent inputs to hippocampus and from hippocampal inhibitory interneurons (Yamamoto and Kawai, 1967; Hounsgaard, 1978; Ben-Ari et al., 1981; Krnjevic, 1981; Krnjevic et al., 1981; Valentino and Dingledine, 1981; Rovira et al., 1983). Application of cholinergic agonists to the pyramidal cell body layer blocks voltage-sensitive $\mathrm{K}^{+}$channels in the pyramidal cells (Krnjevic et al., 1971; Krnjevic and Ropert, 1982; Cole and Nicoll, 1984a, b). Thus, physiological evidence is consistent with the anatomical data in suggesting that the medial scptal cholinergic input, at least in part, terminates upon presynaptic terminals of many elements and possibly onto the soma or dendrites of intrinsic hippocampal neurons.

Anatomical and physiological studies to date have not revealed the existence of relatively small numbers of specific neurons which are heavily targeted by cholinergic input, but there is indirect evidence that such cells exist. In the hippocampus, there are interneurons that are strongly stained for acetylcholinesterase (AChE) after lesion of the medial septum or treat- 
ment with di-isopropylfluorophosphate (DFP) (Shute and Lewis, 1967; Zimmer et al., 1983). In the cerebral cortex and hippocampus there are discrete populations of cells that express AChE but not ChAT (Levey et al., 1984).

Thus, it is conceivable that basal forebrain cholinergic systems project primarily or exclusively to specific target neurons in hippocampus and neocortex. However, it has not been easy in these structures to definitely relate candidate cholinoceptive neurons to other specific cholinergic markers. This is, in part, because both the hippocampus and the neocortex contain intrinsic cholinergic neurons in addition to the extrinsic cholinergic afferents. Because they have not been anatomically related to markers for the cholinergic input, these AChE-positive, ChATnegative neurons have received surprisingly little attention. The possibility that basal forebrain cholinergic neurons terminate selectively on specific classes of interneurons in their cortical targets, however, has important implications, and further consideration of this hypothesis is warranted.

In the present report we describe 2 populations of neurons in the olfactory bulb that express AChE, but not ChAT. The olfactory bulb receives a projection from the horizontal limb of the diagonal band (HDB) in the basal forebrain that is very similar to the medial septal projections to the hippocampus and basal forebrain magnocellular projections to the neocortex (De Olmos et al., 1978; Macrides et al., 1981; Shipley and Adamek, 1984; Brashear et al., 1986; Zaborszky et al., 1986). Compared with hippocampus and neocortex, the olfactory bulb has a simpler cortical organization (Shepherd, 1970) and its interneuronal connections are better understood. As will be shown in this report, the olfactory bulb, unlike the hippocampus and neocortex, does not contain intrinsic cholinergic neurons. Thus, it is possible to ascribe cholinergic markers to afferents from a single subcortical source. The present report describes 2 anatomically distinct populations of AChE-positive, ChAT-negative interneurons and presents evidence for considering thesc ncurons cholinoceptive. Based on this evidence, it is worthwhile to consider the possibility that basal forebrain afferents terminate on specific cholinoceptive neural subpopulations in other cortical structures.

\section{Materials and Methods}

$A C h E$ histochemistry. To visualize the locations and morphologies of AChE-positive neurons in the olfactory bulb, the pharmacohistochemical method of Butcher (1978) was used. In normal AChE-stained material, the cell bodies and processes of AChE-positive cells are obscured by dense neuropil staining. If, however, the animal is treated with a sublethal dose of an irreversible cholinesterase inhibitor, only residual levels of AChE or AChE synthesized after the cholinesterase treatment will be present when the animal is sacrificed. At an appropriate time aftcr the inhibitor, those cells which contain AChE can be seen clearly without the interference of fiber staining.

The irreversible cholinesterase inhibitor, soman (pinacolylmethylphosphonofluoridate; $1.5 \mathrm{mg} / \mathrm{kg}$ ), was injected intramuscularly. Survival times ranged from $30 \mathrm{~min}$ to $60 \mathrm{~d}$. At the selected survival times the animals were deeply anesthetized with pentobarbital and perfused intracardially with fixatives. The brain was then processed for AChE histochemistry according to the method of Van Ooteghem and Shipley (1984). A normal brain was always processed in the same reagent solutions as the experimental brain to monitor fluctuations in reaction conditions.

ChAT immunohistochemistry. Cholinergic fibers and terminals were labeled by immunohistochemistry using monoclonal antibodies (Eckenstein et al., 1981; Eckenstein and Thoenen, 1982; Sofroniew et al. 1982; Eckenstein and Sofroniew, 1983; Levey et al., 1984). Rats were perfused with a brief saline flush, followed by a 2 min perfusion with $0.1 \%$ glutaraldehyde in $0.1 \mathrm{M}$ phosphate buffer (PB), a 30 min perfusion with $4 \%$ paraformaldehyde, $0.1 \%$ glutaraldehyde fixative in $\mathrm{PB}$, and a 30 min perfusion with $4 \%$ paraformaldehyde in PB. The brains were removed and placed in the final fixative solution for $1 \mathrm{hr}$; they were then transferred to $20 \%$ sucrose in $\mathrm{PB}$ and stored at $4^{\circ} \mathrm{C}$ for $24-48 \mathrm{hr}$. The brains were cut at $30 \mu \mathrm{m}$ on a freezing microtome and the sections collected in PB. Improved immunocytochemical staining was obtained when solutions and animals were maintained on ice during the perfusion procedures.

To label ccll bodies containing ChAT, the sections were processed by the PAP method using a double-bridge technique (Ordronneau et al., 1981). The sections were (1) incubated for $1-4 \mathrm{hr}$ in PBS containing $2 \%$ normal goat serum and $0.1-0.25 \%$ Triton $X-100$; (2) rinsed in PBS (2 $\times 15 \mathrm{~min}$ ); (3) incubated in primary antibody (1:25 dilution) overnight on an agitator at $4^{\circ} \mathrm{C} ;(4)$ rinsed in PBS $(2 \times 15 \mathrm{~min}) ;(5)$ incubated in antimouse IgG containing $0.0-0.25 \%$ Triton X-100; (6) rinsed in PBS $(2 \times 15 \mathrm{~min}) ;(7)$ incubated in PAP (Sternberger) conjugates for $1 \mathrm{hr}$; (8) steps 4-7 were repeated (double bridge), and the sections were then reacted for 10-20 $\mathrm{min}$ in $0.05 \%$ diaminobenzidine dihydrochloride (Sig$\mathrm{ma}$ ) and $0.04 \% \mathrm{H}_{2} \mathrm{O}_{2}$, then rinsed in PBS $(3 \times 15 \mathrm{~min})$. The sections were mounted on gelatin-subbed slides and air-dried. In some cases, an osmium intensification procedure was used to enhance the contrast of the stained cells: The mounted sections were defatted, rehydrated, then dipped for $1 \mathrm{~min}$ in $1 \% \mathrm{OsO}_{4}$, rinsed, cleared, and coverslipped.

\section{Results}

\section{Normal AChE staining}

The normal pattern of AChE staining in the rat is shown in Figure 1. There is heavy staining in the glomerular (gl), external plexiform (epl) and internal plexiform (ipl) layers. In the epl, the staining forms 2 bands: The deepest third of the epl and a narrower band just below the glomerular layer are heavily stained; an intermediate band contains relatively little reactivity. The ipl is heavily stained, and there are intensely stained bands in the granule cell layer ( $\mathrm{gcl}$ ). These bands lie between layers of granule cell soma. AChE staining is heaviest in gl, the superficial and deep portions of epl, and in the ipl. The mitral cell layer (mcl) is notably lacking in staining except for unbranched thin processes passing from the ipl to the epl.

Examination of this material at higher magnification reveals structures suggestive of dendrites, fibers, and terminals, but the density of neuropil staining is too great to allow pre- and postsynaptic structures to be distinguished.

\section{Pattern of ChAT-labeled fibers and absence of ChAT-labeled} cell bodies in the olfactory bulb

ChAT activity in the olfactory bulb decreases sharply following lesions of cholinergic neurons in HDB; this suggests that there are no neurons in the olfactory bulb that synthesize this enzyme (Macrides et al., 1981). Such studies cannot, however, rule out the possibility of a small population of ChAT-positive cells. To determine whether such neurons are present, we examined olfactory bulbs stained immunocytochemically with antibodies directed against ChAT. In no case were ChAT-positive neurons found. This is in agreement with other studies that did not report ChAT-positive neurons in the olfactory bulb (Sofroniew et al., 1982; Armstrong et al., 1983; Houser et al., 1983; Rye et al., 1984; Wainer et al., 1984a). Negative immunocytochemical findings must be interpreted with caution since the sensitivity of this method is variable. However, in all our cases, parallel sections through the hippocampus and neocortex reacted at the same time with the same antibodies consistently stained intracortical neurons similar to those reportcd by others (Sofroniew et al., 1982; Armstrong et al., 1983; Houser et al., 1983; Rye et al., 1984). Thus, our immunocytochemical methods were adequately sensitive to stain known cortical cholinergic neurons. Even with a monospecific polyclonal ChAT antibody that stained 

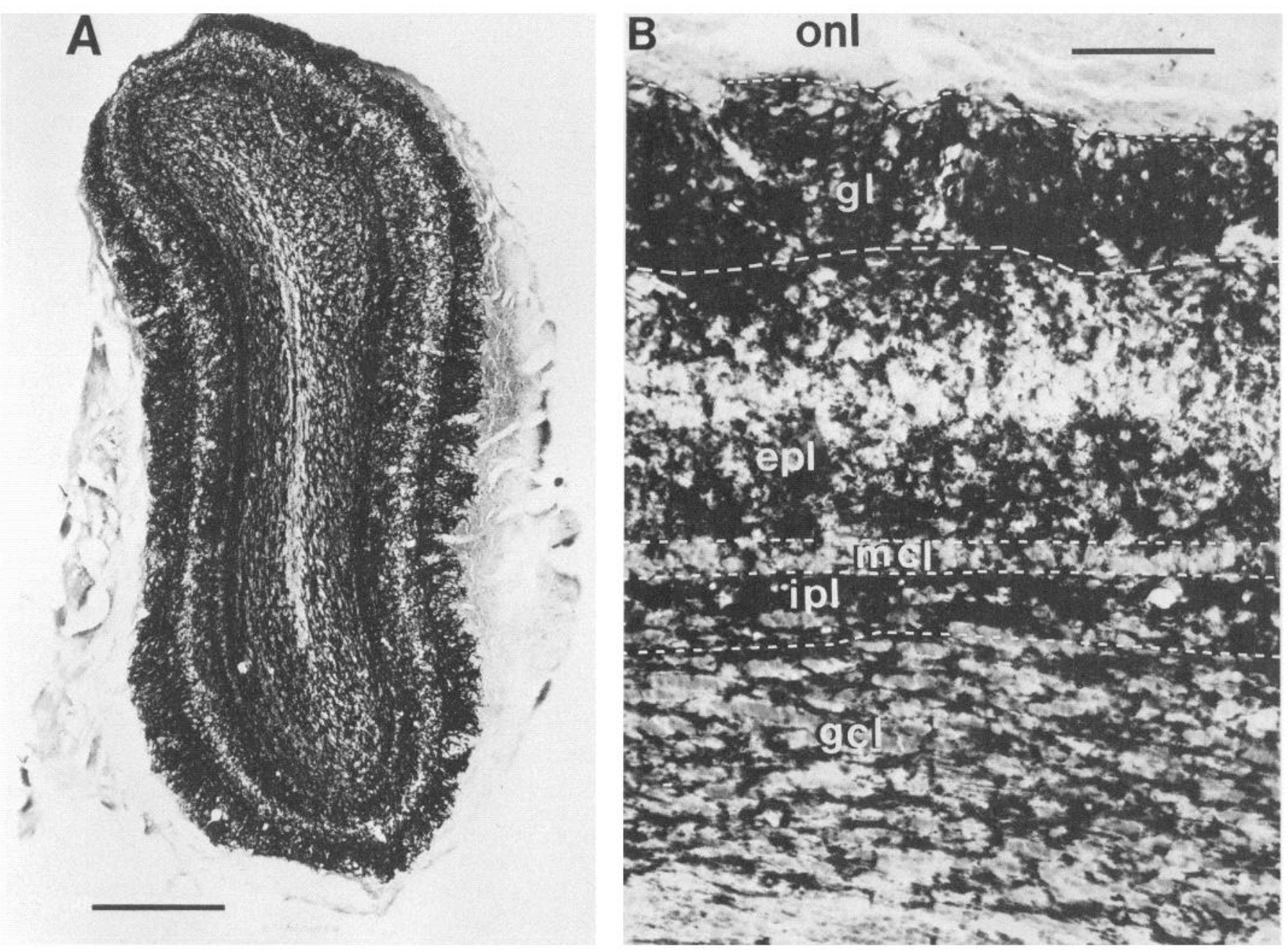

Figure 1. Normal pattern of AChE staining in the olfactory bulb. A, Fifty micron section reacted for AChE according to the method of Van Ooteghem and Shipley (1984). Note heavy labeling in the gl and in a layer just below the mcl and the banded appearance of labeling in the gcl. $B$, Higher-magnification view of AChE staining in olfactory bulb layers. Abbreviations: onl, olfactory nerve layer; $g l$, glomerular layer; $e p l$, external plexiform layer; $\mathrm{mcl}$, mitral cell layer; $i p l$, internal plexiform layer; $g c l$, granule cell layer. Scale bars: $A, 500 \mu \mathrm{m} ; B, 100 \mu \mathrm{m}$.

abundant cholinergic fibers in the olfactory bulb (Shipley et al., in preparation), we were unable to detect ChAT-positive cell bodies. We conclude, therefore, that the olfactory bulb lacks intrinsic cholinergic neurons.

\section{AChE staining after anticholinesterase treatment}

Following soman treatment, AChE staining returns to the olfactory bulb over a period of several days. Almost immediately, however, AChE is detectable in cell bodies within the bulb. In a few cases some cells were stained at $1 \mathrm{hr}$ after intoxication. Staining variability after such short survivals probably reflects differences in the quantity of anticholinesterase reaching the brain. By $8 \mathrm{hr}$ after intoxication, in nearly all cases, there are numerous labeled cell bodies scattered chiefly in a stratum below the mitral cells and in the gl. At longer survival times, staining returns to fibers in the inframitral stratum containing the AChEpositive neurons and visualization of individual cell bodies becomes progressively more difficult. By $14 \mathrm{~d}$ after treatment, some animals show isolated cell bodies with short processes visible, but in most cases the return of $\mathrm{AChE}$ fiber staining is sufficient to obscure cell bodies. By $24 \mathrm{~d}$, the material approaches the normal staining density, in most cases, and AChE-positive neurons are obscured by extensive fiber labeling.

AChE-positive cells are confined to 2 distinct anatomical layers in the olfactory bulb: (1) One population is present in a relatively discrete band just below the $\mathrm{mcl}$, and we will refer to these as inframitral AChE neurons; (2) the second population is confined to the $\mathrm{gl}$ and the superficial third of the epl near the $\mathrm{gl}$; we will refer to these as the juxtaglomerular AChE neurons. AChE-stained neurons were never observed in the middle or deep parts of epl.

In a very few cases, there was a weak, diffuse, silver deposit in the soma of mitral and tufted cells. This deposit was clearly not the typical AChE reaction product, and the cause of this unusual reaction is not known. It may, however, result from staining of damaged or dying cells by the silver-intensification step of the processing, since this procedure is similar to that used to label degenerating cells in classic silver degeneration methods. This artifactual staining may account for earlier reports of AChE activity in olfactory bulb mitral cells (Hunt and Schmidt, 1978a). Whatever the cause of this occasional staining, it is clear that the mitral cells do not express AChE: In our 


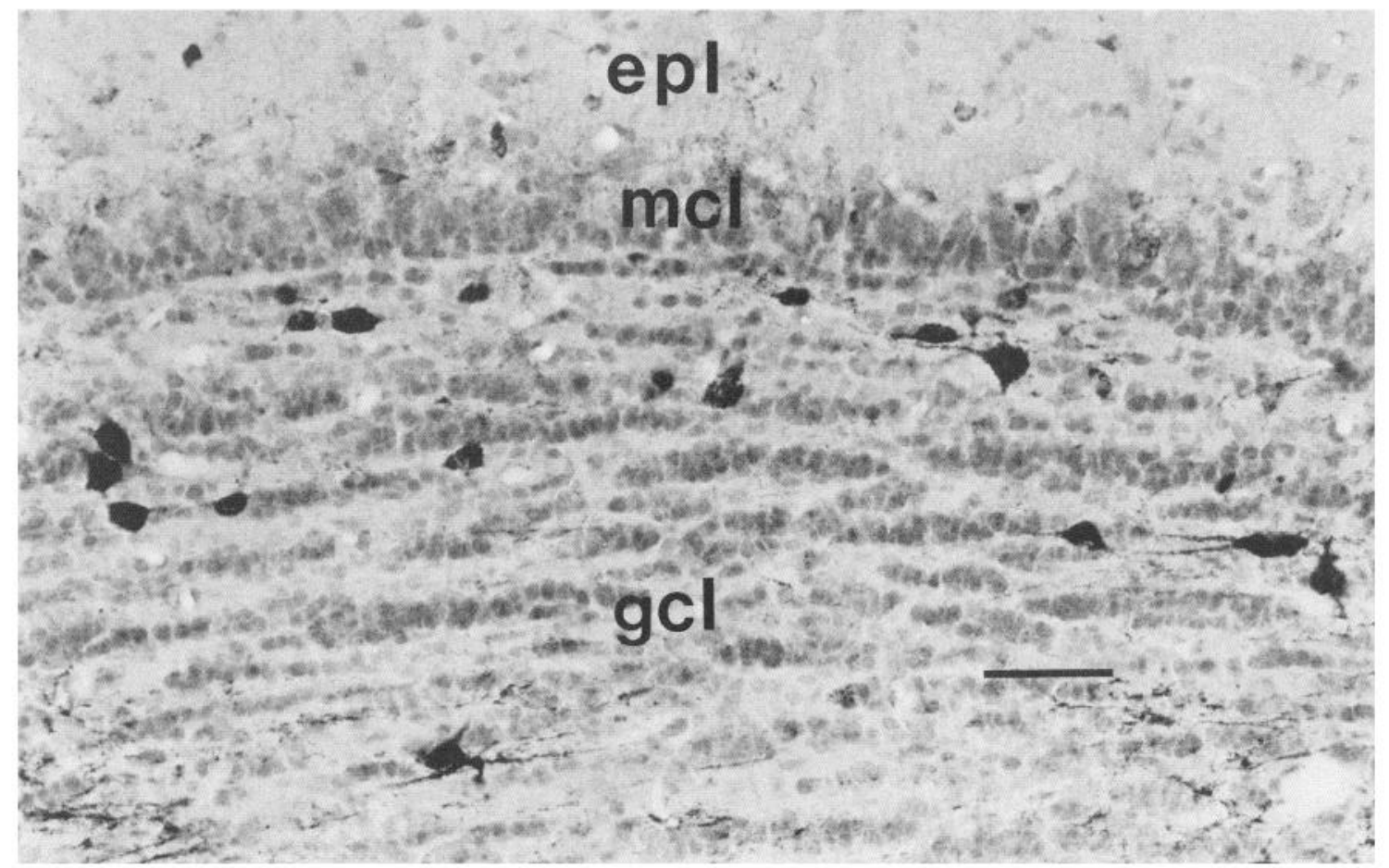

Figure 2. Photomicrograph of AChE-positive cells below the mcl. Twenty-four hour survival. Scale bar, $50 \mu \mathrm{m}$.

normal AChE material the mitral cells are consistently and notably lacking in AChE staining. This is in accord with the histochemical observations of Carson and Burd (1980) in the mouse, Macrides et al. (1981) in the hamster, and with the microdissection biochemical studies of Godfrey et al. (1980) in the rat.

\section{Inframitral AChE-positive cells}

The locations and shapes of the inframitra! AChE cells are indicated in Figure 2, which is a photomicrograph of an olfactory bulb section from an animal that had been treated with soman $24 \mathrm{hr}$ prior to sacrifice. It is apparent that the material is lacking AChE activity except for the heavily labeled cell bodies scattered in a stratum deep to the mcl.

To illustrate the range of shapes and sizes of the inframitral cells and their relationships to the $\mathrm{mcl}$, computer-assisted reconstructions of several microscope fields are presented in Figure 3 . As can been seen, inframitral AChE cells are relatively uniform in size. They are substantially larger than granule cells: In the cases from which the drawings were made, the mean dimensions of inframitral AChE neurons were 10.9 (range, 630; SD 3.9) by 16.3 (range, 9-30; SD 6.30) $\mu \mathrm{m}(n=41)$. This compares with a mean diameter of $8.3 \mu \mathrm{m}$ (range, $5.6-10.8 \mu \mathrm{m}$ ) reported for the soma of granule cells after intracellular injections of HRP (Mori and Kishi, 1982).

Although a few cells are scattered deeper in the gcl, most of the inframitral AChE-positive cells are located in a relatively narrow band just deep to the ipl. This restricted distribution pattern is illustrated in Figure 4, which is a histogram showing the total number of cells in 8 sections as a function of depth below the mcl. The inset in Figure 4 shows the location of all cells in a line drawing of a typical section. In these sections, the distance from mcl to the ependymal zone was about $300 \mu \mathrm{m}$; thus, the axis shown approximately represents the thickness of the gcl. In dorsal and ventral parts of the bulb, the mcl is further from the ependymal layer than it is on the medial and lateral sides of the bulb. Thus, the AChE inframitral neurons appeared to maintain their position relative to the $\mathrm{mcl}$ rather than to the ependymal layer in all parts of the bulb.

After survival times of several days, when labeled fibers and terminal-like staining had began to return to the inner part of the epl, it was frequently possible to follow processes traveling vertically from the gcl to the epl; it was occasionally possible to establish continuity between these processes and a particular AChE-stained cell body. Such fiber staining was seen at survival times too short for staining in afferent cholinergic fibers to have returned. This suggests that the stained processes in the epl belong to the inframitral cells.

\section{Juxtaglomerular AChE cells}

Cholinesterase staining in the gl usually returned more rapidly than that in deeper layers. In many cases, staining was extensive in the $\mathrm{gl}$ when there were no labeled inframitral cells, and no staining in the inner part of epl. In all such short survival time cases, staining in the middle and deep parts of the epl was notably absent. We were never able to trace fibers traversing the epl at such short survival times. These observations strongly suggest that glomerular AChE is not dependent on transport from the inframitral cells or cholinergic afferents; there must be a population of AChE-producing cells in the gl that is responsible for this activity.

We were unable to define the shapes of these juxtaglomerular AChE-positive cells with the same precision as the inframitral cells because the thick dendritic processes of these neurons recovered almost as rapidly as the cell bodies and multiple neurons were stained in each glomerulus (Fig. 5D). Thus, the shapes of the cells were frequently obscured. For this reason we could not determine with certainty whether these neurons represent a morphologically homogeneous group. These neurons comprise only 
Figure 3. Computer-assisted tracings of inframitral cells from a typical case (1 d survival). Dashed lines represent approximate top and bottom of $\mathrm{mcl}$; dotted line represents location of ipl.

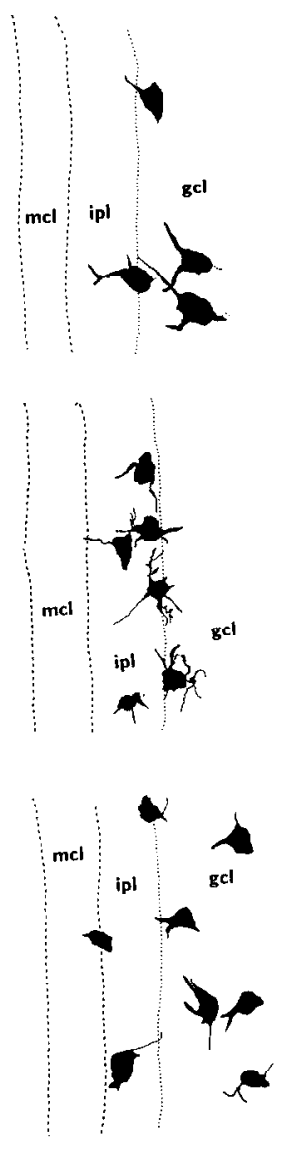

a subpopulation of the juxtaglomerular neurons because in normal, non-AChE-inhibited material, many juxtaglomerular neurons lack $\mathrm{AChE}$ reaction product.

When juxtaglomerular AChE-positive cell bodies could be clearly visualized (Fig. $5 \mathrm{C}$ ), they were located predominantly in the deep half of the $\mathrm{gl}$, but a few labeled cells were located in the superficial epl. A representative sample of juxtaglomerular cells was measured; mean cell size was $14(\mathrm{SD} 4.8) \times 9(\mathrm{SD}$ 1.4) $\mu \mathrm{m}$. These dimensions are somewhat larger than reported for periglomerular cells $(10 \times 8 \mu \mathrm{m})$ but are close to the dimensions reported for external tufted cells $(14 \times 11 \mu \mathrm{m})$ and the short axon cells found in the juxtaglomerular region (Davis and Macrides, 1983).

\section{Numbers of $A C h E$-positive cells}

The number of visible inframitral cells varied appreciably between cases; we assume that this results from variations in both the completeness of the initial $\mathrm{AChE}$ inhibition and rate of return of enzyme. In most animals there was a gradation in the intensity of staining of individual neurons in the population, with some neurons staining intensely and some only weakly labeled. This suggests that the number of identifiable cells increases with the extent of recovery, but, as recovery is also accompanied by the return of dense neuropil staining, there is a point beyond which an accurate assessment of the number of AChE-positive cells becomes impossible. For this reason we can give only a lower limit on the number or density of the inframitral AChE neurons. In the case used to construct Figure 4, the mean number of cells per section was 20.7 (8 sections, SD $=7.3$ ). There are up to 150 such sections in the olfactory bulb;
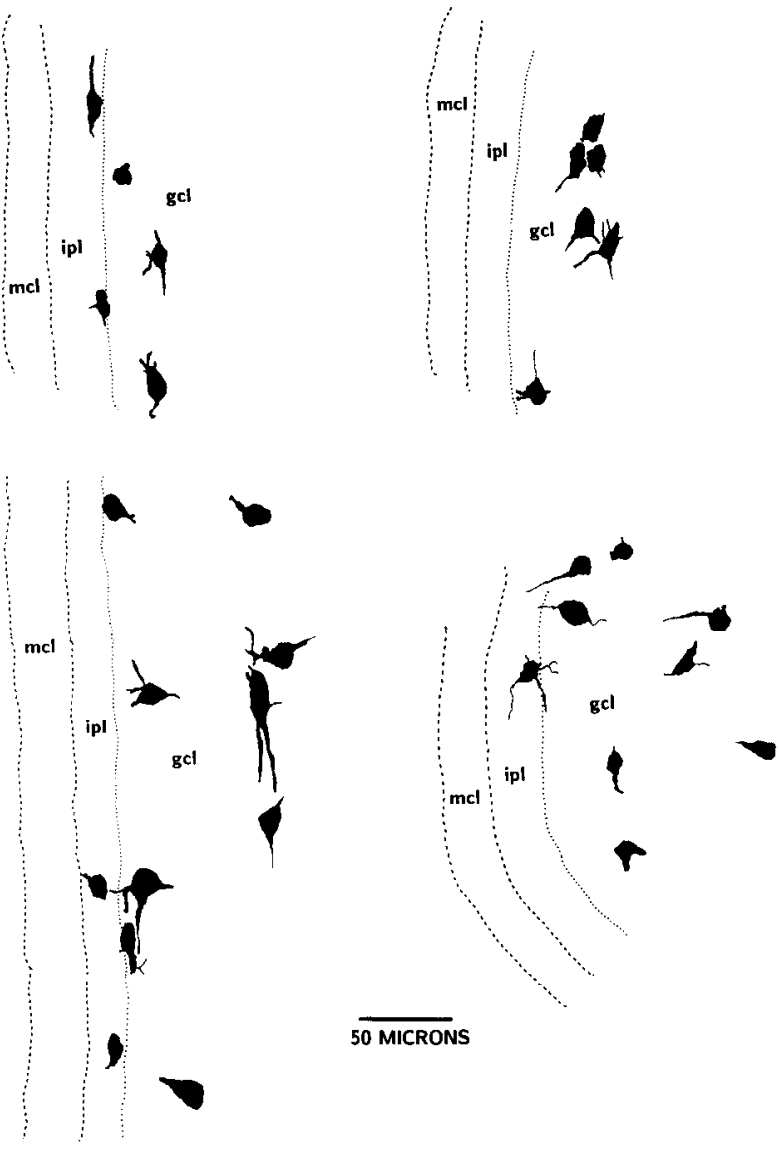

thus, the number of visible inframitral cells in this case would calculate to about 3100 . In cases in which there was more substantial recovery of staining there appeared to be a substantially higher density of cell bodies. In another case in which there was more extensive return of AChE staining, the mean number of visible inframitral cells per section was 63.7 ( 7 sections, $\mathrm{SD}=$ 16.9 ; range, 45-87). In this case, the total number of these cells in the bulb would be about 9500 . These numbers may be compared with the number of mitral cells, which is about 50,000 (rabbit: Allison and Warwick, 1949; rat: Meisami and Safari, 1981). In a companion electrophysiological article we suggest that inframitral AChE neurons mediate (via granule cells) a profound inhibition of mitral cells. The ratio of one AChE neuron to 5 mitral cells is sufficiently low to make this hypothesis plausible.

The number of juxtaglomerular AChE-positive cells is likewise uncertain, but there are probably significantly more of these than the inframitral AChE-positive cells. We estimate that there are 4-8 AChE cells per glomerular profile. There are approximately 80 glomerular profiles in a typical section. Thus, there are 300-600 juxtaglomerular AChE-positive cells in a typical section; if there are 150 sections in the bulb, the total number of such cells in the olfactory bulb is in the range of 45,000 98,000

\section{Discussion}

The present results demonstrate that there are interneurons in the olfactory bulb that express AChE but not ChAT. These neurons comprise 2 distinct subpopulations that are restricted to 2 specific sublayers of the main olfactory bulb. Neurons with- 
in each subpopulation are morphologically similar to each other but are markedly different from neurons in the other subpopulation.

\section{Comparison of AChE-positive cells with cell types identified by Golgi studies}

In the region where the inframitral AChE-positive cells are concentrated, several types of interneuron have been defined by Golgi studies (Schneider and Macrides, 1978). Although it is of interest to speculate that the AChE-positive inframitral cells coincide with one or more of these classes of interneurons, it is difficult to determine which of these classes of neuron is most similar to the AChE-positive cells because delineation of morphological features in our AChE material is not so complete as in Golgi staining. We cannot, for example, see whether the processes of our neurons have spines, nor can we consistently see enough of the dendritic arbors to compare our data with published Golgi profiles. The AChE-positive neurons differ enough in size, morphology, and distribution from granule cells that they are clearly not granule cells. Schneider and Macrides (1978) describe 4 other classes of interneuron which are located in or below the mcl. The laminar distributions of the Golgi-defined inframitral interneurons differ significantly, however. Cajal cells and horizontal cells are restricted to the ipl and part of mcl. Golgi cells occur in part of $\mathrm{mcl}$ and throughout most of gcl; Blanes cells are distributed through most of $\mathrm{gcl}$ but avoid the mcl. The inframitral AChE-positive cells reported here are mainly, but not exclusively, concentrated in the ipl and the superficial part of the gcl, but were rarely seen in the mcl. This distribution does not exactly match that of any of the Golgidefined classes, although the Cajal and horizontal neurons are the most reasonable candidates.

The juxtaglomerular AChE neurons are larger $(14 \times 9 \mu \mathrm{m})$ than typical periglomerular cells, which are approximately $8 \mu \mathrm{m}$ in diameter (Schneider and Macrides, 1978). The AChE neurons are similar in shape and distribution to external tufted cells, many of which are dopaminergic (Davis and Macrides, 1983; Baker, 1986a, b). The only type of interneuron described by Schneider and Macrides (1978) that might correspond to the juxtaglomerular AChE-positive neurons are the superficial short axon cells.

There is good evidence that there are no cells in the olfactory bulb that produce ACh (Macrides et al., 1981; this report); thus, the AChE-positive cells are probably not cholinergic interneurons. It has been suggested (Greenfield, 1984) that AChE may have functions unrelated to cholinergic transmission; however, in the olfactory bulb, the concordance of AChE patterns with other cholinergic markers argues strongly that the primary function of AChE in the olfactory bulb is hydrolysis of acetylcholine. If the neurons described in this report are, in fact, associated with cholinergic transmission in the olfactory bulb, then they are probably postsynaptic to cholinergic terminals. Several lincs of anatomical and physiological evidence are consistent with this hypothesis.

The cell bodies of inframitral AChE-positive neurons are located just deep to the mcl. These neurons appear to send processes both deep into the gcl and superficially into the inner third of the epl. This distribution of processes clearly matches the normal distribution of AChE (this report) and of afferent ChAT-positive fibers (Shipley et al., 1986). The histochemical localization of these cholinergic markers is entirely consistent with the elegant microbiochemical assay studies of Godfrey et

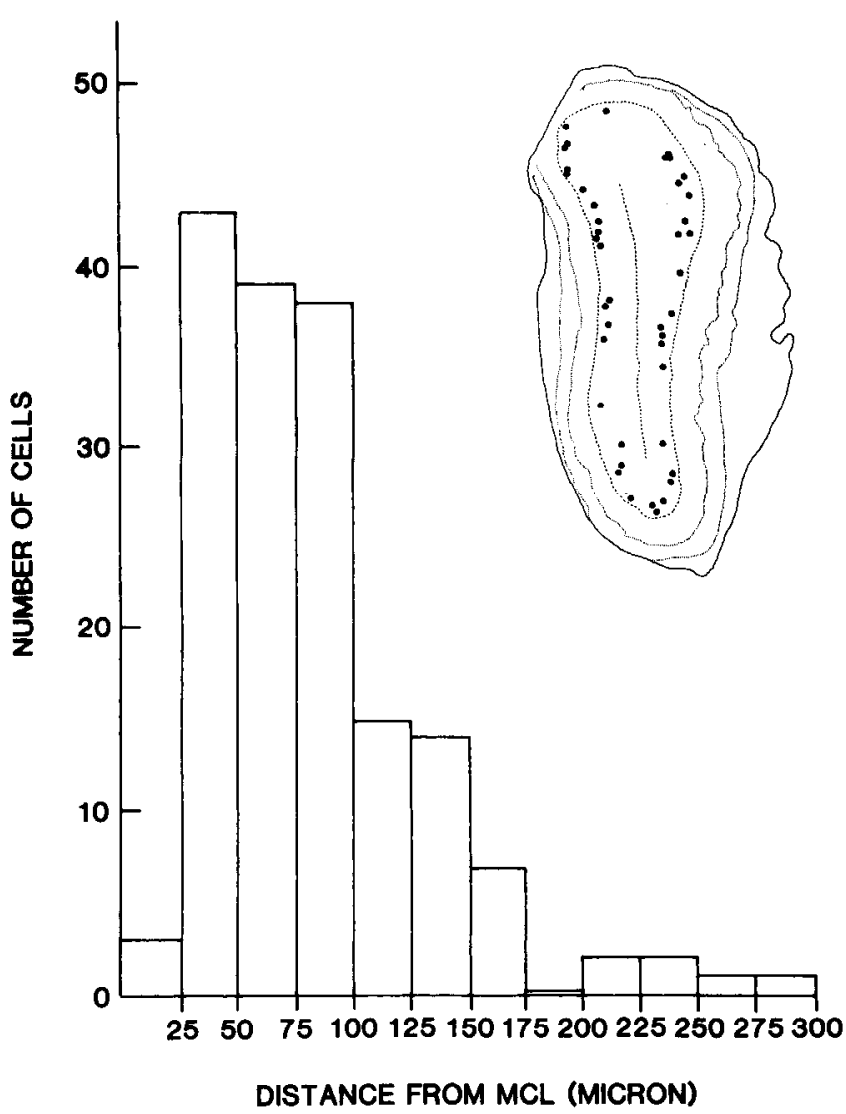

Figure 4. Distribution of AChE-positive inframitral cells. The distance of all labeled cells from the inner edge of mcl was measured in 8 sections through the olfactory bulb. The histogram represents the total number of cells in those 8 sections. Most cells are between 25 and $100 \mu \mathrm{m}$ below the mcl. Seven day survival. Inset, Tracing of a typical bulb section. The location of all clearly visible inframitral AChE-positive cells in that section is represented.

al. (1980) in which AChE and ChAT levels were biochemically assayed in small laminar and sublaminar samples of tissue microdissected from the rat olfactory bulb. These investigators showed that levels of ChAT and AChE are highly correlated and that both enzymes have very high concentrations in the deep and superficial most parts of the epl and the ipl and moderate levels in the gcl. Tracers injected into the nucleus of the diagonal band, the source of cholinergic inputs to the olfactory bulb, produce strong anterograde labeling in the superficial and deep parts of the epl and the ipl and moderate labeling in the gcl (hamster: Macrides et al., 1981; rat: Shipley et al., 1986).

There is a similar concordance of anatomical and histochemical evidence for the glomerular AChE-positive neurons. There is heavy AChE labeling in the gl (Fig. 1, this report; Carson and Burd, 1980; Van Ooteghem and Shipley, 1984). Biochemically measured levels of both ChAT and AChE are higher in the gl than in any other part of the olfactory bulb (Godfrey et al., 1980). Tracers injected into the nucleus of the diagonal band produce strong anterograde labeling in the gl (hamster: Macrides et al., 1981; rat: Shipley et al., 1986), and there is a high density of ChAT-containing afferent fibers in the glomeruli (Shipley et al., 1986; and unpublished observations).

In the olfactory bulb binding of $\alpha$-bungarotoxin ( $\alpha$-BT) is confined to the glomerular region (Hunt and Schmidt, 1978a, b; Schwartz et al., 1982; Blaha et al., 1984). The relation between 

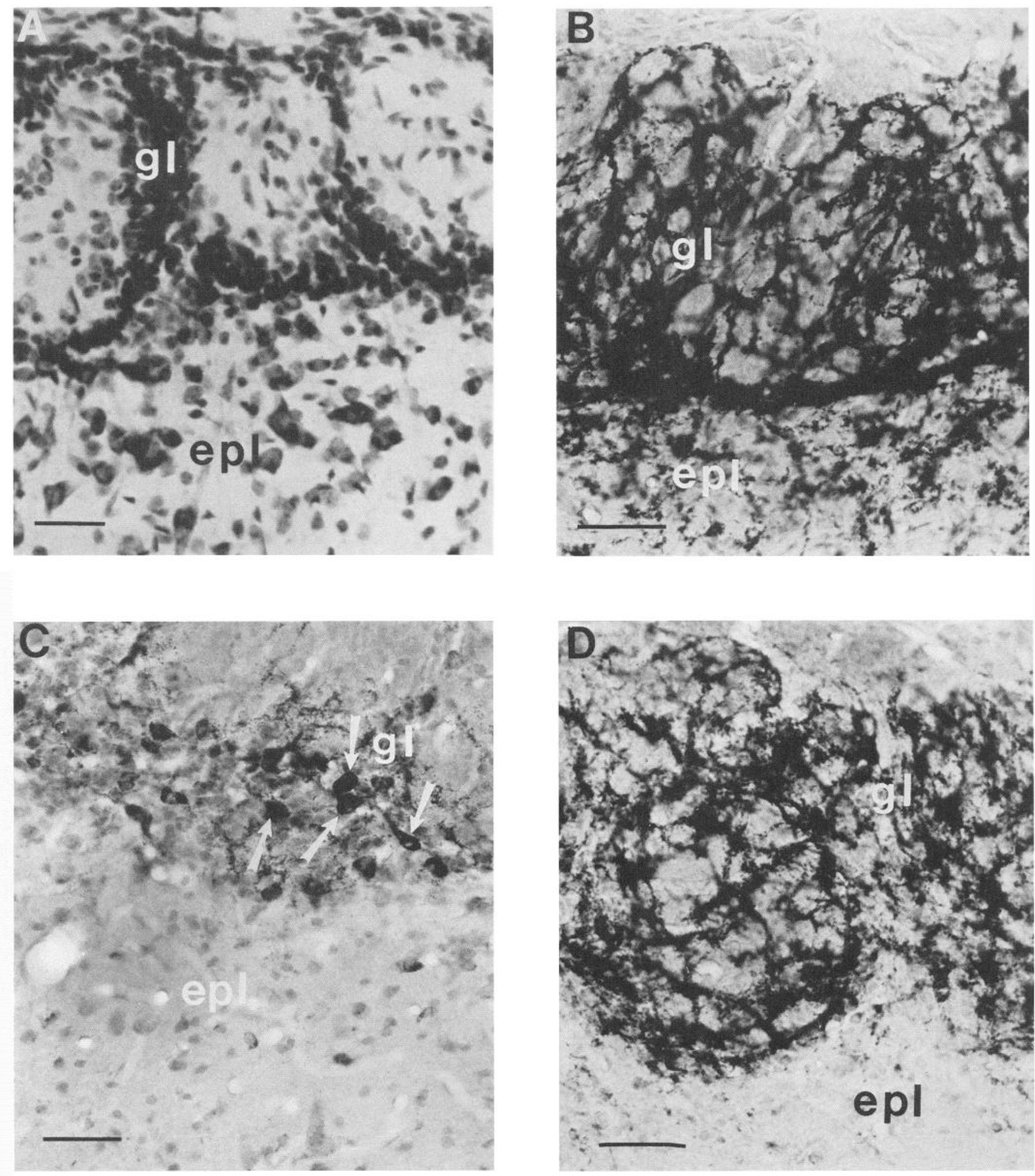

Figure 5. AChE activity in glomerular region following soman treatment. $A$, Normal Nissl material ( $50 \mu \mathrm{m}$ sections). $B$, AChE in a normal, untreated animal. AChE histochemical reaction is weaker than in Figure 1, allowing visualization of AChE-containing structures within the gl. Fiber structure in this normal animal is similar to that in the treated animals, although less detail can be seen. C, AChE-positive cells (arrows) in the gl $24 \mathrm{hr}$ after soman treatment. D, AChE stain in the gl $24 \mathrm{hr}$ after AChE inhibition. Recovery in this case is more extensive. Note that cell bodies can be identified, but their morphology is less clear due to the extensive staining of dendrites. Note also the lack of staining in the epl. The nearly simultaneous recovery of $\mathrm{AChE}$ in the dendrites and cell bodies of these neurons was a common occurrence (see Results). Scale bars: $A$, 50 $\mu \mathrm{m} ; B, 25 \mu \mathrm{m} ; C, 50 \mu \mathrm{m} ; D, 25 \mu \mathrm{m}$. 
$\alpha$-BT and nicotinic receptors in the CNS is not entirely clear (Schwartz et al., 1982). In the glomeruli of the olfactory bulb, however, $\alpha$-BT binding coincides anatomically with a high concentration of other cholinergic markers and the absence of appreciable levels of scopolamine or QNB binding (Blaha et al., 1984; Blaha and Shipley, 1987). Thus, it is possible that there are nicotinic-like receptors in the glomeruli and that the juxtaglomerular AChE-positive neurons have predominantly nicotinic synapses.

By contrast, there is no binding of $\alpha$-BT in the epl, ipl, and $\mathrm{gcl}$, but there is dense binding of muscarinic agonists (Blaha et al., 1984; Blaha and Shipley, 1987). Thus, the inframitral neurons might have predominately muscarinic synapses. The muscarinic binding sites and other cholinergic markers, however, extend more deeply into the gcl than do the inframitral AChEpositive cells. It is possible that these deeper muscarinic binding sites in the gcl are associated with presynaptic cholinergic terminals or centrifugal afferents that terminate in the gcl since there is considerable physiological evidence for cholinergic presynaptic actions in the gcl (Nickell and Shipley, 1987b, c, and in preparation) as in the hippocampus (Yamamoto and Kawai, 1967; Hounsgaard, 1978; Ben-Ari et al., 1981; Krnjevic, 1981; Krnjevic et al., 1981; Valentino and Dingledine, 1981; Cherubini et al., 1982; Rovira et al., 1983).

\section{Implications for function of cholinergic systems}

In summary, the combined results of histochemical, tract tracing, and receptor ligand binding experiments suggest that there are 3 primary sites of cholinergic synaptic action in the olfactory bulb: (1) the gl and the immediately subjacent superficial $10 \%$ of the epl, (2) the zone comprising the ipl, the deep part of the epl, and (3) gcl. The 2 classes of AChE-positive, ChAT-negative interneurons and their processes are, thus, well positioned to be the postsynaptic targets of cholinergic synapses in these sublayers. It is also probable that the cholinergic afferents terminate on presynaptic elements in the gcl (Nickell and Shipley, 1987b, $c$, and in preparation).

The 2 candidate cholinoceptive neurons described here are positioned to influence 2 distinct levels of neural processing in the olfactory bulb. The juxtaglomerular AChE neurons have rich dendritic arbors in the glomeruli. In this region of the olfactory bulb the major neuronal elements are the terminals of the primary olfactory neurons, the apical dendritic arbors of the mitral and tufted cells, and other periglomerular neurons. Thus, cholinergic inputs to the glomerular layer could influence olfactory processing at the first level of synaptic integration.

Inframitral AChE neurons probably do not appreciably influence physiological activity at the level of the glomeruli because there are no known inframitral interneurons with axons or dendrites that reach the gl. In a companion paper we demonstrate that stimulation of the nucleus of the diagonal band causes a significant synaptic potentiation and completely inhibits the spontaneous firing of mitral cells. Analysis of the HDB field potential suggests that there may be a class of inframitral excitatory interneurons that arc excited by the HDB input and activate granule cells, leading to mitral cell inhibition. If this hypothesis is correct, there are both anatomical and physiological grounds for considering that the inframitral neurons are cholinoceptive targets of HDB input and that these neurons exert their influence via granule cells. Thus, inframitral AChE neurons may function by operating at the second major level of synaptic integration in the olfactory bulb-granulc-mitral cell interactions.

Conceivably, both classes of AChE neurons influence mitral cells but in different ways. Mitral cells have 2 distinct dendritic branches. The principal apical dendrite extends generally without branching through the epl to ramify specifically in a single glomerulus. AChE-positive juxtaglomerular neurons may influence this glomerular dendritic arbor. The secondary dendrites of mitral cells ramify in the epl, where they receive extensive inhibitory synapses from granule cells. $\mathrm{HDB}$ excitation of inframitral AChE neurons and their subsequent activation of granule cells would account for the inhibition of mitral cell spontaneous firing (Nickell and Shipley, 1987a, 1988). Therefore, inframitral AChE neurons may influence the activity of mitral cells via activation of granule cell inhibitory synapses on the secondary lateral dendrites of mitral cells and juxtaglomerular AChE ncurons may influence mitral cells by acting on the primary apical dendrites in the glomeruli. Physiological experiments to determine the potential cholinergic influence of juxtaglomerular AChE neurons on mitral cell principal dendrites have not been done, but the present analysis forms the basis for several specific predictions: (1) Cholinergic agonists applied at the gl should modulate the effect of olfactory nerve stimulation on mitral cell activity, (2) this action should be mediated by nicotinic synapses, (3) cholinergic agonists applied in the ipl should excite an interneuron via a muscarinic receptor, and (4) this muscarinic action should modify synaptic events on the lateral, nonglomerular dendrites of mitral cells and thus not directly influence transmission from the olfactory nerve to $\mathrm{mi}-$ tral cells.

In the hippocampus and neocortex, there are also AChEpositive, ChAT-negative neurons that are similar in size and morphology to the inframitral neurons described here; thus, such neurons may be a common feature of other cortical structures innervated by basal forebrain cholinergic neurons. These cells do not appear to be especially numerous; however, their physiological functions might still be significant (Nickell and Shipley, 1987a, 1988). Hence, further evidence for specific classes of cholinoceptive target neurons could have important implications for our understanding of cholinergic modulation of cortical activity. The existence of specific classes of cholinoceptive target neurons might also have significance for our understanding of the perturbations of cholinergic inputs to cortex in Alzheimer's disease-the loss of cholinoceptive target neurons might be an initial event that results, secondarily, in the degeneration or shrinkage of afferent cholinergic neurons (Sofroniew et al., 1987).

\section{References}

Allison, A. C., and R. T. T. Warwick (1949) Quantitative observations on the olfactory system in the rabbit. Brain 72: 186-197.

Amaral, D. G., and J. Kurz (1985) An analysis of the origins of the cholinergic and noncholinergic septal projections to the hippocampal formation of the rat. J. Comp. Neurol. 240: 37-59.

Armstrong, D. M., C. B. Saper, A. I. Levey, B. H. Wainer, and R. D. Terry (1983) Distribution of cholinergic neurons in rat brain: Demonstrated by the immunocytochemical localization of choline acetyltransferase. J. Comp. Neurol. 216: 53-68.

Baker, H. (1986a) Species differences in the distribution of Substance $\mathrm{P}$ and tyrosine hydroxylase immunoreactivity in the olfactory bulb. J. Comp. Neurol. 252: 206-226.

Baker, H. (1986b) Substance $P$ and tyrosine hydroxylase are localized in different neurons of the hamster olfactory bulb. Exp. Brain Res. 65: $245-249$. 
Ben-Ari, Y., K. Krnjevic, W. Reinhardt, and N. Ropert (1981) Intracellular observations on the disinhibitory action of acetylcholine in the hippocampus. Neuroscience 6: 2475-2484.

Blaha, G. C., and M. T. Shipley (1987) Muscarinic cholinergic binding sites in the main olfactory bulb (MOB) of the rat. Anat. Rec. 218: 17A

Blaha, G., W. Blair, W. T. Nickell, and M. T. Shipley (1984) Cholinergic $(\mathrm{CH})$ receptors in the rat olfactory bulb: Nicotinic $(N)$ and muscarinic $(\mathrm{M})$ cholinergic receptors are segregated and coincide with acetylcholinesterase (AChE). Neurosci. Soc. Abstr. 10(2): 1183.

Brashear, H. R., L. Zaborszky, and L. Heimer (1986) Distribution of GABAergic and cholinergic neurons in the rat diagonal band. Neuroscience 17: 439-451.

Butcher, L. L. (1978) Recent advances in histochemical techniques for the study of central cholinergic mechanisms. In Cholinergic Mechanisms and Psychopharmacology, D. J. Jenden, ed., pp. 93-124, Plenum, New York.

Carson, K. A., and G. D. Burd (1980) Localization of acetylcholinesterase in the main and accessory olfactory bulbs of the mouse by light and electron microscopic histochemistry. J. Comp. Neurol. 191: 353-371.

Chandler, J. P., and K. A. Crutcher (1983) The septohippocampal projection in the rat: An electron microscopic horseradish peroxidase study. Neuroscience 10:685-696.

Cherubini, E., C. Rovina, Y. Ben-Ari, and A. Padjen (1982) Simultaneous recording of somatic and dendritic field potentials and combined microiontophoresis in rat ammon's horn in situ: Effects of GABA and ACh. Neurosci. Lett. 31: 19-24.

Cole, A. E., and R. A. Nicoll (1984a) The pharmacology of cholinergic excitatory responses in hippocampal pyramidal cells. Brain Res. 305: 283-290.

Cole, A. E., and R. A. Nicoll (1984b) Characterization of a slow cholinergic post-synaptic potential recorded in vitro from rat hippocampal pyramidal cells. J. Physiol. (Lond.) 352: 173-188.

Coyle, J. T., D. L. Price, and M. K. DeLong (1983) Alzheimer's disease-A disorder of cortical cholinergic innervation. Science 219: $1184-1190$.

Davis, B. J., and F. Macrides (1983) Tyrosine hydroxylase immunoreactive neurons and fibers in the olfactory system of the hamster. J. Comp. Neurol. 214: 427-440.

De Olmos, J., H. Hardy, and L. Heimer (1978) The afferent connections of the main and the accessory olfactory bulb formations in the rat: An experimental HRP-study. J. Comp. Neurol. 181: 213-244.

Eckenstein, F., and M. V. Sofroniew (1983) Identification of central cholinergic neurons containing both cholinacetyltransferase and acetylcholinesterase and of central neurons containing only acetylcholinesterase. J. Neurosci. 3: 2286-2291.

Eckenstein, F., and H. Thoenen (1982) Production of specific antisera and monoclonal antibodies to choline acetyltransferase: Characterization and use for identification of cholinergic neurons. EMBO J. 1: 363-368.

Eckenstein, F., Y. A. Barde, and H. Thoenen (1981) Production of specific monoclonal antibodies to choline acetyltransferase purified from pig brain. Neuroscience 6: 993-1000.

Eckerman, D. A., W. A. Gordon, J. D. Edwards, R. C. MacPhail, and M. I. Gage (1980) Effects of scopolamine, pentobarbital, and amphetamine on radial arm maze performance in the rat. Physiol. Behav. 12: 595-602.

Frotscher, M., and C. Leranth (1985) Cholinergic innervation of the rat hippocampus as revealed by choline acetyltransferase immunocytochemistry: A combined light and electron microscopic study. J. Comp. Neurol. 239: 237-246.

Godfrey, D. A., C. D. Ross, A. D. Herrmann, and F. M. Matschinsky (1980) Distribution and derivation of cholinergic elements in the rat olfactory bulb. Neuroscience 5: 273-292.

Greenfield, S. (1984) Acetylcholinesterase may have novel functions in the brain. Trends Neurosci. 7: 364-368.

Hounsgaard, J. (1978) Presynaptic inhibitory action of acetylcholine in area CA1 of the hippocampus. Exp. Neurol. 62: 787-797.

Houser, C. R., G. D. Crawford, R. P. Barber, P. M. Salvaterra, and J. E. Vaughn (1983) Organization and morphological characteristics of cholinergic neurons: An immunocytochemical study with a monoclonal antibody to choline acetyltransferase. Brain Res. 266:97-119.

Hunt, S., and J. Schmidt (1978a) Are mitral cells cholinergic? In Society for Neuroscience Symposia, Vol. 3, Aspects of Behavioral Neu- robiology, J. A. Ferrendelli, cd., pp. 204-218, Society for Neuroscience, Bethesda, MD.

Hunt, S., and J. Schmidt (1978b) Some observations on the binding patterns of $\alpha$-bungarotoxin in the central nervous system of the rat. Brain Res. 157: 213-232.

Krnjevic, K. (1981) Acetylcholine as modulator of amino-acid-mediated synaptic transmission. In The Role of Peptides and Amino Acids as Neurotransmitters, B. J. Lombardini and A. D. Kenny, eds., pp. 127-141, Liss, New York.

Krnjevic, K., and N. Ropert (1982) Electrophysiological and pharmacological characteristics of facilitation of hippocampal population spikes by stimulation of the medial septum. Neuroscience 7:21652183.

Krnjevic, K., R. Pumain, and L. Renaud (1971) The mechanism of action of acetylcholine in the cerebral cortex. J. Physiol. (Lond.) 215: 247-268.

Krnjevic, K., R. J. Reiffenstein, and N. Ropert (1981) Disinhibitory action of acetylcholine in the rat's hippocampus: Extracellular observations. Neuroscience $6: 2465-2474$.

Levey, A. I., B. H. Wainer, D. B. Rye, E. J. Mufson, and M.-M. Mesulam (1984) Choline acetyltransferase-immunoreactive neurons intrinsic to rodent cortex and distinction from acetylcholinesterase-positive neurons. Neuroscience 13: 341-353.

Macrides, F., B. J. Davis, W. M. Youngs, N. S. Nadi, and F. L. Margolis (1981) Cholinergic and catecholaminergic afferents to the olfactory bulb in the hamster: A neuroanatomical, biochemical and histochemical investigation. J. Comp. Neurol. 203: 495-514.

Meisami, E., and L. Safari (1981) Quantitative study of the effects of early unilateral olfactory deprivation on the number of mitral and tufted cell in the rat olfactory bulb. Brain Res. 221: 81-107.

Mesulam, M.-M., E. J. Mufson, A. I. Levey, and B. H. Wainer (1983a) Cholinergic innervation of cortex by the basal forebrain: Cylochemistry and cortical connections of the septal area, diagonal band nuclei, nucleus basalis (substantia innominata), and hypothalamus in the rhesus monkey. J. Comp. Neurol. 214: 170-197.

Mesulam, M.-M., E. J. Mufson, B. H. Wainer, and A. I. Levey (1983b) Central cholinergic pathways in the rat: An overview based on an alternative nomenclature (Ch1-Ch6). Neuroscience 10:1185-1201.

Mori, K., and K. Kishi (1982) The morphology and physiology of the granule cells in the rabbit olfactory bulb revealed in the intracellular recording and HRP injection. Brain Res. 247: 129-133.

Nickell, W. T., and M. T. Shipley (1987a) Frequency potentiation of a central cholinergic circuit. J. Neural Transm. (Suppl.) 24: 153-160.

Nickell, W. T., and M. T. Shipley (1987b) Prolonged inhibition of contralateral and potentiation of ipsilateral association inputs to the olfactory bulb by stimulation of the diagonal band. Soc. Neurosci. Abstr. 13: 1400.

Nickell, W. T., and M. T. Shipley (1987c) Prolonged inhibition of anterior commissure input to the olfactory bulb by stimulation of the diagonal band. Chem. Senses 12:688.

Nickell, W. T., and M. T. Shipley (1988) Neurophysiology of magnocellular forebrain inputs to the olfactory bulb in the rat: Frequency potentiation of field potentials and inhibition of output neurons. $\mathbf{J}$. Neurosci. 8: 4492-4502.

Ordronneau, P., P. B.-M. Lindstrom, and P. Petrusz (1981) Four unlabelled antibody bridge techniques: A comparison. J. Histochem. Cytochem. 29: 1397-1404.

Rovira, C., Y. Ben-Ari, E. Cherubini, K. Krnjevic, and N. Ropert (1983) Pharmacology of the dendritic action of acetylcholine and further observations on the somatic disinhibition in the rat hippocampus in situ. Neuroscience 8: 97-106.

Rye, D. B., B. H. Wainer, M.-M. Mesulam, E. J. Mufson, and C. B. Saper (1984) Cortical projections arising from the basal forebrain: A study of cholinergic and non-cholinergic components employing combined retrograde tracing and immmunohistochemical localization of choline acetyltransferase. Neuroscience 13: 627-643.

Schneider, S. P., and F. Macrides (1978) Laminar distribution of interneurons in the main olfactory bulb of the adult hamster. Brain Res. Bull. 3: 73-82.

Schwartz, R. D., R. McGee, Jr., and K. Kellar (1982) Nicotinic cholinergic receptors labelled by $\left[{ }^{3} \mathrm{H}\right]$-acetylcholine in rat brain. Mol. Pharmacol. 22: 56-62.

Shepherd, G. M. (1970) The olfactory bulb as a simple cortical system: Experimental analysis and functional implications. In The Neuro- 
sciences: Second Study Program, F. O. Schmitt, ed., pp. 539-552, Rockefeller University Press, New York.

Shipley, M. T., and G. D. Adamek (1984) The connections of the mouse olfactory bulb: A study using orthograde and retrograde transport of wheat germ agglutinin conjugated to horseradish peroxidase. Brain Res. Bull. 12: 669-688.

Shipley, M. T., W. T. Nickell, and J. H. McLean (1986) Organization of afferents from the nucleus of the diagonal band to the olfactory bulb. Chem. Senses 11:663.

Shute, C. C. D., and P. R. Lewis (1967) The ascending cholinergic reticular system: Neocortical olfactory and subcortical projections. Brain 90: 497-520.

Sofroniew, M. V., F. Eckenstein, H. Thoenen, and A. C. Cuello (1982) Topography of choline acetyltransferase-containing neurons in the forebrain of the rat. Neurosci. Lett. 33: 7-12.

Sofroniew, M. V., R. C. A. Pearson, and T. P. S. Powell (1987) The cholincrgic nuclei of the basal forebrain of the rat: Normal structure, development and experimentally induced degeneration. Brain Res. 411: 310-331.

Valentino, R. J., and R. Dingledine (1981) Presynaptic inhibitory effect of acetylcholine in the hippocampus. J. Neurosci. 1: 784-792.

Van Ooteghem, S. A., and M. T. Shipley (1984) Factors affecting the sensitivity and consistency of the Koelle-Friedenwald histochemical method for localization of acetylcholinesterase. Brain Res. Bull. 12: 543-553.

Wainer, B. H., A. I. Levey, E. J. Mufson, and M.-M. Mesulam (1984a) Cholinergic systems in mammalian brain identified with antibodies against choline acetyltransferase. Neurochem. Int. 6: 163-182.
Wainer, B. H., J. P. Bolam, T. F. Freund, Z. Henderson, S. Totterdell, and A. D. Smith (1984b) Cholinergic synapses in rat brain: A correlated light and electron microscopic immunohislochemical study employing a monoclonal antibody against choline acetyltransferase. Brain Res. 308: 69-76.

Wainer, B. H., A. I. Levey, D. B. Rye, M.-M. Mesulam, and E. J. Mutson (1985) Cholinergic and non-cholinergic septohippocampal pathways. Neurosci. Lett. 54: 45-52.

Watts, J., R. Stevens, and C. Robinson (1981) Effects of scopolamine on radial maze performance in rats. Pharmacol. Biochem. Behav. 26: 845-851.

Whitehouse, P. J., D. L. Price, A. W. Clark, J. T. Coyle, and M. R. DeLong (1981) Alzheimer's disease: Evidence for selective loss of cholinergic neurons in nucleus basalis. Ann. Neurol. 10: 122-126.

Whitehouse, P. J., D. L. Price, R. G. Struble, A. W. Clark, J. T. Coyle, and M. R. DeLong (1982) Alzheimer's disease and senile dementia: Loss of neurons in the basal forebrain. Science 215: 1237-1239.

Yamamoto, C., and N. Kawai (1967) Presynaptic action of acetylcholine in thin sections from the guinea pig dentate gyrus in vitro. Exp. Neurol. 19: 176-187.

Zaborszky, L., J. Carlsen, H. R. Brashear, and L. Heimer (1986) Cholinergic and GABAergic afferents to the olfactory bulb in the rat with special emphasis on the projection from the horizontal limb of the diagonal band. J. Comp. Neurol. 243: 488-509.

Zimmer, J., S. Laurberg, and N. Sunde (1983) Neuroanatomical aspects of normal and transplanted hippocampal tissue. In Neurobiology of the Hippocampus, W. Seifert, ed., pp. 39-64, Academic, New York. 